\author{
Magdalena Stopiak* \\ ORCID: 0000-0001-8498-7671 \\ Uniwersytet Jagielloński
}

DOI: $10.19195 / 1733-5779.25 .9$

\title{
Wyrażanie zgody przez walne zgromadzenie akcjonariuszy spółki akcyjnej na zbycie składników jej majątku
}

JEL Classificiation: K120

Słowa kluczowe: spółka akcyjna, zgoda walnego zgromadzenia akcjonariuszy, uchwała akcjonariuszy

Keywords: a capital company, sale of the Company's assets, shareholders' resolution

Abstrakt: Celem artykułu jest analiza spornych zagadnień dotyczących wymogu wyrażenia zgody przez walne zgromadzenie akcjonariuszy w spółce akcyjnej w przypadkach prowadzących do zbycia składników majątku spółki kapitałowej. Podjęta została analiza koncepcji, które wskazują skutki wywoływane przez czynność prawną prowadzącą do zbycia składników majątku spółki bez zgody walnego zgromadzenia akcjonariuszy, a także problemy praktyczne samych regulacji opisanych $\mathrm{w}$ art. 393 k.s.h. Podane zagadnienia rozważane są z uwzględnieniem stanu faktycznego, relewantnych z punktu widzenia praktycznego, poprzez skonfrontowanie poglądów prezentowanych przez doktrynę i orzecznictwo. Analizie poddano możliwość sprzedaży udziałów spółki zależnej bez zgody walnego zgromadzenia akcjonariuszy, a także konieczność wyrażenia zgody w przypadku zawarcia umowy przedwstępnej do sprzedaży nieruchomości, wchodzącej w skład majątku spółki kapitałowej. Autorka niniejszego artykułu stara się odpowiedzieć na pytanie, który z prezentowanych poglądów jest słuszniejszy w świetle obowiązującego stanu prawnego.

\section{The consent of the general meeting of the shareholders of a joint stock company for the sale of assets of this company}

\begin{abstract}
The aim of the article is to analyze the disputable issues regarding the requirement of consent passed by ownership entities the shareholders' meeting and the general meeting of shareholders, respectively in a limited liability company and a joint-stock company. The author indicates results of infringement of article 393 and 288 Code of Commercial Companies, as well
\end{abstract}

* Opiekun naukowy (Scientific Tutor) - Andrzej Szumański 
as the practical problems on the ground of those regulation of presented issues are considered on the basis of actual states, which are relevant from a practical point of view. Thorough analysis helps to identify a view which is better in the light of the binding legal status.

\section{Wprowadzenie}

Istotną rolę w strukturze spółki akcyjnej odgrywa walne zgromadzenie akcjonariuszy, które sprawuje nadzór nad strategicznymi decyzjami w spółce ${ }^{1}$. Artykuł 393 Kodeksu spółek handlowych ${ }^{2}$ statuuje główne kompetencje walnego zgromadzenia akcjonariuszy poprzez enumeratywne wyliczenie przypadków, w których wymagana jest zgoda akcjonariuszy spółki. Podjęcie uchwały w sprawach wyliczonych w tym artykule jest w większości obligatoryjne. Imperatywny charakter uchwał $^{3}$ podkreśla ich doniosłą rolę. We wspomnianym przepisie wymieniono najważniejsze z punktu widzenia interesu spółki czynności prawne oraz transakcje, które mogą mieć istotny wpływ na jej kondycję oraz dalszą działalność. Ze względu na ich wagę konieczne jest potwierdzenie ich przez organ właścicielski — walne zgromadzenie akcjonariuszy. Obowiązek uzyskania zgody w formie uchwały walnego zgromadzenia akcjonariuszy wynika z tego, że organ ten skupia w swoim gronie właścicieli akcji ${ }^{4}$, którzy lokując swój kapitał w majątku spółki, powinni mieć kontrolę nad kluczowymi decyzjami związanymi z nią. Taki element kontroli chroni akcjonariuszy przed nielojalnym zachowaniem menedżerów spółki, którzy zajmując się bieżącą obsługą korporacyjną, mają możliwość podejmowania wielu relewantnych decyzji w spółce. Ponadto należy pamiętać, że zgodnie $\mathrm{z}$ art. $375^{1} \mathrm{k}$.s.h. walne zgromadzenie akcjonariuszy w spółce akcyjnej nie może wywierać wpływu na decyzje zarządu, gdyż nie jest uprawnione do wydawania mu wiążących poleceń, a to tylko podkreśla doniosłą rolę wymogu zgody walnego zgromadzenia akcjonariuszy do podjęcia wyliczonych w ustawie czynności.

Ocena, czy dane decyzje powinny trafić pod rozwagę walnego zgromadzenia akcjonariuszy, prowadzi do rozbieżności poglądów w doktrynie i orzecznictwie. Praktyczne problemy rodzi pojemność przesłanek wymienionych w art. 393 k.s.h. Wątpliwości może również potęgować fakt, że ustawa nie reguluje w sposób zupełny okoliczności, w których wymagana jest uchwała organu właścicielskiego. Zarówno ustawodawca, jak i statut spółki mogą wskazywać inne obszary, w których taka zgoda w formie uchwały będzie wymagana. Dlatego powstaje pytanie, jak szeroka interpretacja pojęć zawartych w ustawie jest dopuszczalna.

${ }^{1}$ M. Spyra, [w:] System Prawa Handlowego, t. 2. Prawo spółek handlowych, red. S. Włodyka, Warszawa 2012, s. 1214.

${ }^{2}$ Ustawa z dnia 15 września 2000 roku Kodeks spółek handlowych, Dz.U. z 2000 r. Nr 94, poz. 1037, dalej: k.s.h.

3 S. Sołtysiński, [w:] Kodeks spótek handlowych, t. 3. Spótka akcyjna. Komentarz do artykutów 301-490, red. S. Sołtysiński et al., Warszawa 2009, s. 537.

${ }^{4}$ Ibidem. 


\section{Skutki braku zgody walnego zgromadzenia akcjonariuszy spółki na czynności prawne, które mogą mieć istotne znaczenie dla spółki}

Przed przystąpieniem do analizy konkretnych przypadków oraz oceny konieczności wyrażenia zgody $\mathrm{w}$ formie uchwały przez walne zgromadzenie akcjonariuszy na czynności prawne, które mogą być istotne z punktu widzenia spółki, należy wskazać, jakie skutki wywoła brak uchwały organu właścicielskiego. Z samej hipotezy przepisu art. 393 k.s.h. wynika jedynie obowiązek udzielenia zgody na określone czynności prawne przez walne zgromadzenie akcjonariuszy. W przepisie nie wyartykułowano wprost skutków braku takiej uchwały. Odpowiedzi na to pytanie należy szukać w art. $17 \S 1$ k.s.h., stanowiącym, że czynność dokonana bez zgody wymaganej przez ustawę powoduje jej nieważność. Ta regulacja na pierwszy rzut oka wydaje się klarowna, jednak nie jest jasne, jaki charakter należy przyznać czynności prawnej dokonanej bez zgody określonej w art. 393 k.s.h. Wątpliwości narastają w związku z art. 17 § 2 k.s.h., w którym wskazano, że zgoda może być udzielona zarówno przed, jak i po dokonaniu danej czynności, nie później jednak niż w terminie dwóch miesięcy od złożenia oświadczenia przez spółkę 5 .

Według jednego z poglądów na kanwie tego przepisu możliwe jest przyjęcie, że czynność prawna jest nieważna i może zostać konwalidowana w wyniku późniejszej uchwały walnego zgromadzenia akcjonariuszy ${ }^{6}$. Autorzy reprezentujący niniejszy pogląd wskazują na literalne brzmienie art. 17 k.s.h., tym samym odwołując się do art. 2 k.s.h. w związku z art. 58 k.c. ${ }^{7}$, na podstawie którego czynność ta będzie uznana za nieważną, zaś w momencie potwierdzenia stanie się ważna z mocą wsteczną. Artykuł 58 k.c. jako zasadę przewiduje nieważność danej czynności prawnej, gdy jest ona sprzeczna z ustawą. Aby przyjąć inny skutek danej czynności, na przykład bezskuteczność zawieszoną, należy wskazać ku temu osobną podstawę prawną, której w tym wypadku nie sposób się doszukać.

Stojąc na tym stanowisku, prof. M. Rodzynkiewicz wskazuje dodatkowo, że dopiero po upływie dwumiesięcznego terminu można tak naprawdę dowiedzieć się, czy dana czynność będzie nieważna, czy też ważna ex tunc ${ }^{8}$. Wiąże się to $z$ dopuszczeniem możliwości cofnięcia zgody wyrażonej przez walne zgromadzenie akcjonariuszy. Oczywiście takie uchylenie zgody odbywa się w oznaczonym terminie, przewidzianym przez ustawę w art. 17 k.s.h. Tym samym, przyjmując to stanowisko, nie jest możliwe stwierdzenie przed upływem dwumiesięcznego terminu, czy dana czynność jest ważna. Wydaje się jednak, że taka konstatacja idzie za daleko, pozostawiając zbyt szerokie pole do nadużyć, co może zostać wykorzystane przez akcjonariuszy. Możliwy do wyobrażenia jest bowiem przypadek,

5 Art. 17 ustawy z dnia 15 września 2000 roku Kodeks spółek handlowych.

6 M. Rodzynkiewicz, Kodeks spótek handlowych. Komentarz, Warszawa 2012, s. 55-57.

7 Ustawa z dnia 23 kwietnia 1964 roku Kodeks cywilny, Dz.U. z 1964 r. Nr 16, poz. 93, dalej: k.c.

${ }^{8}$ M. Rodzynkiewicz, op. cit., s. 55-57. 
w którym akcjonariusze wyrażą zgodę na zbycie nieruchomości w formie uchwały, na podstawie której zawarta zostanie umowa sprzedaży tej nieruchomości. Następnie zgoda zostanie cofnięta, co doprowadzi do tego, że po zawarciu przedmiotowa umowa sprzedaży nieruchomości okaże się bezwzględnie nieważna. Godzi to w pewność obrotu i narusza zaufanie drugiej strony kontraktu. Niesie to za sobą także przedłużanie stanu niepewności, w którym tkwią osoby, które chcą oprzeć swoje działania na uchwale podjętej przez walne zgromadzenie akcjonariuszy. Tym samym tak daleko idący pogląd nie zasługuje na aprobatę, jednak nie podważa to słuszności samej konstrukcji konwalidacji nieważnej czynności prawnej.

Inne stanowisko zakłada, że w sytuacji braku uchwały walnego zgromadzenia akcjonariuszy znajdzie zastosowanie konstrukcja bezskuteczności zawieszonej czynności prawnej, której ważność zależeć będzie od potwierdzenia jej w odpowiednim terminie ${ }^{9}$. Aby przeanalizować zasadność tego twierdzenia, należy odwołać się do istoty bezskuteczności zawieszonej. Profesor S. Grzybowski zwraca uwagę, że w sytuacji, gdy zgoda nie zostaje udzielona ani przed dokonaniem czynności, ani w jej trakcie, mamy do czynienia z negotium claudicans ${ }^{10}$. W czasie między dokonaniem czynności a upływem terminu na wyrażenie zgody panuje stan zawieszenia, a taka czynność przez okres dwóch miesięcy nie jest ani ważna, ani nieważna ${ }^{11}$. Jednakże by móc powołać się na koncepcję czynności prawnej kulejącej konieczne jest potwierdzenie tej czynności. Wskazywałoby to na podobieństwo konstrukcji wyrażonej w art. $17 \S 2$ k.s.h. do koncepcji zgody osoby trzeciej wyrażonej w art. 63 k.c. ${ }^{12}$ Jednakże takie zapatrywanie nie zasługuje na aprobatę ze względu na to, że nie można uznać organu spółki kapitałowej, jakim jest walne zgromadzenie akcjonariuszy, za osobę trzecią w stosunku do spółki. Zgromadzenie jest bowiem organem właścicielskim spółki, a nie podmiotem niezależnym od spółki, zatem nie jest możliwe uznanie takiej czynności prawnej za bezskutecznie zawieszoną.

Analiza przedstawionych konsekwencji czynności dokonanej bez zgody walnego zgromadzenia akcjonariuszy wywołuje doniosłe konsekwencje praktyczne, zarówno dla samej spółki, jak i dla osób, które dokonały przedmiotowej czynności prawnej ze spółką, gdyż przesądza, czy dana czynność prawna w ogóle wywrze skutki w obrocie prawnym. Należy zgodzić się z prof. S. Sołtysińskim, twierdzącym, że sam charakter art. 17 k.s.h., wyrażony poprzez krótki termin do podjęcia uchwały przez walne zgromadzenie akcjonariuszy, ma mieć dla akcjonariuszy znaczenie dyscyplinujące. Oznacza, to że art. 17 k.s.h. ma na celu doprowadzenie

9 G. Suliński, [w:] Komentarz KSH, red. J. Bieniak et al., Kodeks spótek handlowych. Komentarz, Warszawa 2011, s. 120.

10 S. Grzybowski, O rzekomej konwalidacji nieważnej czynności prawnej, „Ruch Prawniczy, Ekonomiczny i Socjologiczny" 1974, nr 3, s. 42-45.

11 Ibidem.

12 K. Rudnicki, Uzależnienie działania zarządu spółki kapitałowej od decyzji innych organów spótki, ,Monitor Prawniczy” 2000, nr 7, s. 43 n. 
do pewności w obrocie prawnym w najkrótszym możliwym czasie ${ }^{13}$. W związku z tym słuszna wydaje się koncepcja mówiąca o konwalidacji nieważnej czynności prawnej w wypadku wyrażenia następczo zgody przez walne zgromadzenie akcjonariuszy. Nie sposób bowiem stwierdzić, że sam organ spółki jest osobą trzecią wobec samej spółki, a zatem niezasadne wydaje się przyjęcie koncepcji bezskuteczności zawieszonej, do której zgoda byłaby potrzebna. Ponadto art. 17 k.s.h. nie określa skutków niezachowania konieczności zgody organu w formie uchwały, a to wymaga skorzystania z odesłania ustanowionego w art. 2 k.s.h., który w przypadkach nieuregulowanych w niniejszej ustawie stanowi, że zastosowanie znajdą przepisy Kodeksu cywilnego. W konsekwencji, w przypadku podjęcia uchwały sprzecznej z ustawą, należy posłużyć się literalnym brzmieniem art. $58 \S 1$ k.c., który nakazuje przyjęcie sankcji nieważności jako skutku tej czynności prawnej.

Należy również zwrócić uwagę na dodatkowe zabezpieczenie przewidziane w Kodeksie spółek handlowych — jeśli czynność zostanie podjęta bez uprzedniej zgody walnego zgromadzenia akcjonariuszy, może ona prowadzić także do odpowiedzialności odszkodowawczej członków władz spółki. W takim wypadku, na podstawie art. 483 k.s.h., ich działania zostaną poddane ocenie z punktu widzenia odpowiedzialności odszkodowawczej wobec spółki. Członkowie zarządu, rady nadzorczej oraz likwidatorzy mogą się jednak zwolnić od odpowiedzialności, gdy wykażą brak swojej winy ${ }^{14}$.

\section{Zbycie pakietu udziałów spółek zależnych}

Przechodząc do właściwej analizy kompetencji walnych zgromadzeń, dotyczącej zbycia składników majątku spółki, należy podkreślić, że w art. 393 pkt 3) k.s.h. wskazane jest, że „zbycie i wydzierżawienie części przedsiębiorstwa lub jego zorganizowanej części oraz ustanowienie na nich ograniczonego prawa rzeczowego wymaga uchwały walnego zgromadzenia" ${ }^{15}$. Warto odwołać się do regulacji Kodeksu cywilnego, w którym $\mathrm{w}$ art. $55^{1}$ k.c. przedsiębiorstwo zostało przedstawione w ujęciu przedmiotowym ${ }^{16}$ i wyliczono jedynie przykładowo („w szczególności”), co może wchodzić w jego skład. W rozumieniu tego przepisu przedsiębiorstwem jest zbiór tych praw majątkowych i niemajątkowych połączony przez osobę zarządzającą przedsiębiorstwem, tworzący zorganizowaną całość, a decydującą determinantą jest sam zbiór rzeczy, nie jest zaś istotny czynnik podmiotowy ${ }^{17}$.

13 S. Sołtysiński, P. Moskwa, [w:] System Prawo Prywatnego, t. 17B. Prawo spółek kapitałowych, red. S. Sołtysiński, Warszawa 2016, s. 647.

14 Wyrok SN z dnia 10 listopada 2004 roku, II CK 186/04, LEX nr 197641.

15 Art. 393 ustawy z dnia 15 września 2000 roku Kodeks spółek handlowych.

16 R. Morek, [w:] Komentarze Prawa Prywatnego, t. 1. Przepisy wprowadzajace, część ogólna. Własność i inne prawa rzeczowe, red. K. Osajda, Warszawa 2017, s. 465.

17 M. Pełczyński, Przedsiębiorstwo (art. 55[1] KC) wielopodmiotowe - istota i reżim prawny (cz. I), „Monitor Prawniczy” 2017, nr 3, s. 135. 
Niejednokrotnie w skład majątku spółki wchodzą także udziały lub akcje innych spółek (często zależnych). W takiej sytuacji spółka, która posiada udziały lub akcje wielu spółek, może zostać określona jako dominująca (,spółka matka”), zwłaszcza gdy ma znaczny wpływ na decyzje spółek zależnych. W praktyce problem pojawia się, gdy w ramach grupy spółek ,spółka matka” zajmuje się jedynie zarządzaniem pozostałymi podmiotami, nie podejmując faktycznie żadnej innej działalności. Działalność takiej spółki skupia się wtedy w szczególności na odpowiednim zarządzaniu całą grupą, koordynowaniu zadań grupy, udzielaniu licencji pozostałym spółkom itp. ${ }^{18}$ Pojawił się zatem problem — czy słuszne jest uznanie za zbycie przedsiębiorstwa lub jego zorganizowanej części sytuacji, w której dochodzi do zbycia pakietu rzeczonych udziałów lub akcji spółek zależnych przez spółkę dominującą. Taka sprawa trafiła do Sądu Najwyższego w 2002 roku, jeszcze na podstawie Kodeksu handlowego ${ }^{19}$. Niewątpliwie wyrok ten pozostaje aktualny w obecnym stanie prawnym, gdyż wówczas obowiązujący art. 162 pkt 3 k.h. również wymagał uchwały walnego zgromadzenia akcjonariuszy w wypadku zbycia przedsiębiorstwa ${ }^{20}$.

W przedmiotowym przykładzie spółka akcyjna (dominująca) sprzedaje pakiet udziałów w spółkach z ograniczoną odpowiedzialnością (spółkach zależnych). W związku z tym powstaje wątpliwość, czy zbycie pakietu udziałów można potraktować jako zbycie części przedsiębiorstwa. By rozstrzygnąć tę kwestię, należy zastanowić się, co jest przedmiotem zbycia na podstawie tej umowy sprzedaży. Przedmiotowa umowa o zbycie udziałów w spółkach zależnych niewątpliwie dotyczy samych uprawnień właścicielskich, czyli własności spółek (każdej spółki z osobna), nie zaś wszystkich jako jednej, integralnej całości, w której jedna ze spółek nie może egzystować w oderwaniu od pozostałych. W wyroku z dnia 23 października 2003 roku $^{21}$ orzeczono, że spółka dominująca, powołująca się na istnienie przedmiotu przedsiębiorstwa $\mathrm{w}$ postaci powiązań finansowo-organizacyjnych łączących spółkę dominującą i zależną, nie wystarczy do stwierdzenia, że mamy do czynienia z przedsiębiorstwem w rozumieniu art. $55^{1}$ k.c., gdyż nie zostało wykazane dostateczne powiązanie relacji poszczególnych spółek. Jednakże w tym samym uzasadnieniu Sąd Najwyższy wskazał, że dotyczy to konkretnego przypadku opisanego w tym stanie faktycznym. Zaakcentowano, że nie zostało dostatecznie dowiedzione przez spółkę powodową, że w podanym stanie faktycz-

18 A. Opalski, Prawo zgrupowań spółek, Warszawa 2012, s. 222 n.

19 Rozporządzenie Prezydenta Rzeczypospolitej z dnia 27 czerwca 1934 roku Kodeks handlowy, Dz.U. z 1934 r. Nr 57, poz. 502.

20 Art. 221 pkt 3 rozporządzenia Prezydenta Rzeczypospolitej z dnia 27 czerwca 1934 roku Kodeks handlowy: „Uchwały Spólników oprócz innych spraw, wymienionych w dziale niniejszym lub umowie spółki, wymagają: [...] 3) Zbycia i wydzierżawienia przedsiębiorstwa oraz ustanowienia na nim prawa użytkowania".

21 Wyrok SN z dnia 23 października 2003 roku, sygn. V CK 411/02, „Monitor Prawniczy” 2004, 2004/9/417. 
nym nastąpiła sprzedaż przedsiębiorstwa w rozumieniu Kodeksu cywilnego, a to na spółce spoczywał obowiązek wykazania wszelkich relewantnych okoliczności zgodnie $\mathrm{z}$ art. 6 k.c. Należy podkreślić, że w czasie orzekania trudno było mówić o zorganizowanej działalności podmiotów w grupach kapitałowych, z jaką spotykamy się obecnie. Wiąże się to z organicznymi możliwościami, jakie panowały w ówcześnie obowiązujących regulacjach prawnych, które nie były wtedy tak elastyczne, chociażby przez brak utartej praktyki dotyczącej prawa holdingowego. Obecnie, w związku ze zwiększającą się ekspansją gospodarczą spółek, coraz większą atrakcyjnością cieszy się zawiązywanie grup spółek, które umożliwiają ograniczenie ryzyka gospodarczego, a także walkę z rosnącą konkurencją na rynku. W skomplikowanej strukturze powiązań między spółkami wielokrotnie mamy do czynienia z klarownym podziałem obowiązków w grupie, w której spółka dominująca koordynuje wszelkie działania podejmowane przez spółki zależne. W konsekwencji spółki córki są uzależnione od decyzji spółki matki.

W wyroku Sądu Najwyższego wskazano brak dostatecznego uzasadnienia powiązania między działalnością spółki dominującej a podmiotami zależnym w zakresie zarządzania właścicielskiego. Tym samym można wnioskować, że Sąd Najwyższy nie wykluczył kategorycznie możliwości przyjęcia, że sprzedaż udziałów spółki zależnej można traktować jako zbycie przedsiębiorstwa. Słusznie zauważono w doktrynie, że nawet Polska Klasyfikacja Działalności przewiduje w swoim zbiorze możliwość skoncentrowania działalności na zarządzaniu i kontrolowaniu innych spółek ${ }^{22}$, co tylko potwierdza możliwość uznania takiej działalności spółki dominującej za przedsiębiorstwo w rozumieniu Kodeksu cywilnego. Jednak wydaje się, że dodatkowo należy wykazać inne składniki materialne, które niejako połączą spółki zależne w jedną całość, wskazując ścisłe relacje między nimi a spółką dominującą. Nie można zatem wykluczyć możliwości przyjęcia takiej koncepcji, gdy wykaże się odpowiednie powiązanie funkcjonalno-organizacyjne między poszczególnymi przedmiotami wchodzącymi w skład przedsiębiorstwa. Na przeszkodzie może stać okoliczność, że w Polsce większość holdingów funkcjonujących w praktyce stanowią holdingi faktyczne ${ }^{23}$, brakuje zatem dostatecznego zorganizowania wewnętrznego i samodzielności podmiotów, co jest konieczne do uznania danego fragmentu za część przedsiębiorstwa w rozumieniu art. $55^{1}$ k.c. Wydaje się jednak, że jest to możliwe i zależy od dowodów przemawiających za powiązaniem spółek - w postaci regulaminów grup spółek czy kodeksów etycznych grup spółek.

22 Zob. M. Pełczyński, op. cit., s. 141; zob. także sekcja Polskiej Klasyfikacji Działalności: M, PKD-70: Działalność firm centralnych (head offices); doradztwo związane z zarządzaniem.

23 A. Szumański, [w:] System Prawa Prywatnego, t. 17A. Prawo spółek kapitałowych, red. S. Sołtysiński, Warszawa 2015, s. 797. 


\section{Zawarcie umowy przedwstępnej do sprzedaży nieruchomości}

Zbycie nieruchomości jest kolejną czynnością odnośnie do której wymagana jest zgoda w formie uchwały walnego zgromadzenia akcjonariuszy. Regulacja przewidziana w art. 393 pkt 4) k.s.h. nie ma jednak charakteru imperatywnego, gdyż ustawa pozwala na wyłączenie wymogu podjęcia uchwały w statucie spółki. Takie wyłączenie będzie niezbędne zwłaszcza w działalności deweloperskiej, gdyż każdorazowe występowanie o zgodę walnego zgromadzenia akcjonariuszy przy zbywaniu poszczególnych nieruchomości wchodzących w skład spółki byłoby całkowicie nieracjonalne $\mathrm{z}$ gospodarczego punktu widzenia. Jednak poza wymienionym przypadkiem umowa zbycia nieruchomości może mieć kluczowe znaczenie dla działalności spółki (na przykład poprzez lokalizację biur, magazynów lub innej infrastruktury na terenie nieruchomości), ważne jest zatem, aby akcjonariusze spółki mogli mieć wpływ na jej zawarcie. Oczywiście możliwe jest również wyłączenie kompetencji do wyrażenia zgody przez walne zgromadzenie akcjonariuszy na rzecz innego podmiotu, co może być motywowane większą operatywnością innego organu, na przykład rady nadzorczej.

Warto się zastanowić, czy w hipotezie art. 393 pkt 4) k.s.h. mieści się także zawarcie umowy przedwstępnej do zawarcia umowy sprzedaży nieruchomości, czy jest ona stricte ograniczona tylko do czynności prawnej przenoszącej własność nieruchomości. Analizę należy rozpocząć od wskazania skutków, jakie może wywrzeć umowa przedwstępna sprzedaży nieruchomości, by następnie móc odnieść się do regulacji zawartej w Kodeksie spółek handlowych. Zgodnie z art. 390 § 1 i 2 k.c. w zależności od formy, w jakiej zostanie zawarta umowa przedwstępna, możliwe są dwa skutki tej czynności prawnej — tzw. słabszy oraz silniejszy. W pierwszym przypadku umowa przedwstępna nie doprowadzi do zawarcia umowy przyrzeczonej na drodze przymusowej. Umowa bez zachowania formy przewidzianej dla umowy przyrzeczonej (formy aktu notarialnego w przypadku nieruchomości, co wynika z art. 158 k.c.) w razie uchylania się od obowiązku zawarcia umowy sprzedaży kreuje jedynie roszczenie odszkodowawcze na podstawie art. $390 \S 1$ k.c. ${ }^{24} \mathrm{w}$ granicach ujemnego interesu umownego ${ }^{25}$. Drugi, tzw. silniejszy, skutek może prowadzić w konsekwencji do zawarcia umowy przyrzeczonej, albowiem na podstawie umowy w formie aktu notarialnego możliwe jest żądanie złożenia przez dłużnika przed sądem oświadczenia o przeniesieniu własności. Gdy to nie nastąpi, sąd na mocy art. 64 k.c. w zw. z art. 1047 k.p.c. ${ }^{26}$ może wydać orzeczenie

24 M. Krajewski, [w:] System Prawa Prywatnego, t. 5. Prawo zobowiąań - część ogólna, red. E. Łętowska, Warszawa 2012, s. 908.

25 W. Popiołek, [w:] Kodeks cywilny, t. 1, red. K. Pietrzykowski, Warszawa 2015, s. 1282.

26 Ustawa z dnia 17 listopada 1964 roku Kodeks postępowania cywilnego, Dz.U. z 1964 r. $\mathrm{Nr}$ 43, poz. 296, dalej: k.p.c. 
sądu stwierdzające zawarcie umowy i zastępujące tę umowę ${ }^{27}$. Finalnie własność przejdzie na podmiot uprawniony w treści umowy przedwstępnej do nabycia nieruchomości. Nastąpi to jednak na podstawie orzeczenia sądu stwierdzającego zawarcie umowy sprzedaży, nie zaś na podstawie samej umowy przedwstępnej.

Interpretując kompetencję do wyrażenia zgody na zbycie lub nabycie nieruchomości, można wyróżnić dwa rozwiązania, które zostały przedstawione w wyroku Sądu Najwyższego z dnia 6 lutego 2009 roku $^{28}$. Według pierwszego z nich możliwe jest przyjęcie szerokiego rozumienia kompetencji walnego zgromadzenia akcjonariuszy, tym samym obligując ten organ spółki akcyjnej do zaakceptowania już samej umowy przedwstępnej zbycia lub nabycia nieruchomości ${ }^{29}$. Umowa może być uznana za czynność prowadzącą do zbycia lub nabycia nieruchomości, co można by uznać za słuszne, interpretując 393 k.s.h. w kontekście jego funkcji - zabezpieczenia uprawnień właścicieli. Umowa przedwstępna o tzw. silniejszym skutku może bowiem na drodze zastępczego oświadczenia woli doprowadzić do zawarcia przed sądem umowy przenoszącej własność na drodze powództwa o świadczenie ${ }^{30}$.

Jednak nie jest to trafne stanowisko w kontekście wyjątkowego charakteru art. 393 k.s.h. Wyliczono w nim czynności, które podlegają zatwierdzeniu przez walne zgromadzenie akcjonariuszy. Podkreśla to szczególny charakter tego przepisu, należy go zatem interpretować w sposób zawężający, biorąc pod uwagę przede wszystkim wykładnię literalną. Warto wskazać, że ustawodawca intencjonalnie użył pojęć „zbycie”, „nabycie”, które wskazują na przeniesienie własności nieruchomości, tj. wywołanie skutku rozporządzającego. Za takim rozumowaniem podążał także skład orzekający, który wskazał, że umowa przedwstępna do zawarcia umowy sprzedaży nieruchomości nie wymaga uchwały walnego zgromadzenia akcjonariuszy. Zgodnie z literalnym brzmieniem tego przepisu uchwały wymagają jedynie czynności prawne rozporządzające, skutkujące przeniesieniem własności nieruchomości na inny podmiot w rozumieniu art. $155 \S 1$ k.c. $\mathrm{c}^{31}$. Sama zaś umowa przedwstępna nie jest podstawą do późniejszego przeniesienia własności nieruchomości na uprawniony z jej tytułu podmiot. Co prawda na podstawie art. 64 k.c. w związku z art. 1047 k.p.c. możliwe jest żądanie przez podmiot uprawniony zawarcia umowy przyrzeczonej przed sądem. W przypadku braku złożenia oświadczenia woli o przeniesieniu własności może to nastąpić w wyni-

27 Uchwała Sądu Najwyższego 7 sędziów — zasada prawna z dnia 7 stycznia 1967 roku, III CZP 32/66, OSNC 1968/12/199.

${ }^{28}$ Wyrok SN z dnia 6 lutego 2009 roku, sygn. IV CSK 271/08, LEX nr 529733.

29 R. Kwaśnicki, P. Letolc, Brak konieczności uzyskania zgody walnego zgromadzenia akcjonariuszy na zawarcie umowy przed wstępnej zobowiąujacej do przeniesienia własności nieruchomości, [w:] Prawo spótek handlowych. Orzecznictwo 2009-2010, red. R. Kwaśnicki, P. Letolc, Legalis/el. 2011.

30 Postanowienie SN z dnia 22 grudnia 1997 roku, III CZ 104/97, Legalis Nr 44354.

31 Ibidem. 
ku oświadczenia woli wydanego przez sąd ${ }^{32}$. Jednak w wyniku zawarcia samej umowy przedwstępnej do sprzedaży nieruchomości nie nastąpi zbycie lub nabycie nieruchomości, albowiem ma to miejsce w wyniku zawarcia osobnej umowy lub orzeczenia sądu (gdyby miało to miejsce przed sądem). To zaś prowadzi do konstatacji, że w przypadku zawierania umowy przedwstępnej nie aktualizuje się hipoteza art. 393 k.s.h., gdyż sama umowa przedwstępna, nawet o tzw. silniejszym skutku, nie przenosi własności nieruchomości. Co za tym idzie, nie jest konieczna do tej czynności uchwała walnego zgromadzenia akcjonariuszy.

\section{Podsumowanie}

Powyższe rozważania podkreślają istotność uchwał walnego zgromadzenia akcjonariuszy w przypadku zbywania składników majątku należącego do spółki lub podejmowania czynności prowadzących do zbycia składników majątku spółki. Przede wszystkim duże znaczenie odgrywa brak dostatecznej regulacji związanej z prawem holdingowym, umożliwiającej bardziej adekwatną ocenę odnośnie do tego, co można uznać za przedsiębiorstwo w rozumieniu art. $55^{1}$ k.c. Wydaje się jednak, że nie należy przesądzać z góry, że nie jest możliwe uznanie za prowadzenie przedsiębiorstwa działalności opartej na zarządzaniu innymi spółkami. W praktyce, biorąc pod uwagę obecne powiązania grup spółek, możliwe będzie wykazanie, że w konkretnym przypadku będziemy mieć do czynienia z przedsiębiorstwem, którego działalność skupia się wyłącznie na zarządzaniu innymi spółkami. Jednak w związku z brakiem dostatecznych dowodów na powiązania między spółkami należy tę regulację interpretować zgodnie z jej celem — ochroną akcjonariuszy. Podobnie w kwestii zawarcia umowy przedwstępnej do zawarcia umowy nabycia lub zbycia nieruchomości nie jest uprawnione stosowanie wykładni rozszerzającej, zgodnie z łacińską regułą exceptiones non sunt extendendae. W konsekwencji wydaje się, że do zawierania samej umowy przedwstępnej nie jest konieczna zgoda akcjonariuszy wyrażona w formie uchwały.

Wszystko prowadzi do wniosku, że w aktualnie obowiązującym porządku prawnym kompetencje przewidziane w art. 393 pkt 3) i 4) k.s.h. należy interpretować zawężająco, gdyż są to uregulowania wyjątkowe, ograniczające się jedynie do zbywania składników majątku spółki o znacznej wartości oraz dużej istotności dla kondycji spółki, a sama regulacja ustawowa nie daje podstaw do przyjmowania wykładni rozszerzającej.

Poczynione uwagi można przenieść na grunt spółki z ograniczoną odpowiedzialnością, uwzględniając różnice w konstrukcji spółki akcyjnej i spółki z ograniczoną odpowiedzialnością. Należy między innymi pamiętać o braku zakazu wydawania wiążących poleceń zarządowi w spółkach z ograniczoną odpowiedzialnością, który występuje w odniesieniu do spółki akcyjnej.

32 Uchwała Sądu Najwyższego 7 sędziów... 


\section{Bibliografia}

Bieniak J. et al., Kodeks spótek handlowych. Komentarz, Warszawa 2011.

Grzybowski S., O rzekomej konwalidacji nieważnej czynności prawnej, „Ruch Prawniczy, Ekonomiczny i Socjologiczny" 1974, nr 3.

Kodeks cywilny, t. 1, red. K. Pietrzykowski, Warszawa 2015.

Kodeks spótek handlowych, t. 3. Spółka akcyjna. Komentarz do artykułów 301-490, red. S. Sołtysiński, A. Szajkowski, A. Szumański, J. Szwaja, Warszawa 2009.

Kodeks spótek handlowych. Komentarz, red. M. Rodzynkiewicz, Warszawa 2012.

Komentarze Prawa Prywatnego, t. 1, Przepisy wprowadzające, część ogólna. Własność i inne prawa rzeczowe, red. K. Osajda, Warszawa 2017.

Kwaśnicki R., Letolc P., Brak konieczności uzyskania zgody walnego zgromadzenia akcjonariuszy na zawarcie umowy przedwstępnej zobowiazującej do przeniesienia własności nieruchomości, [w:] Prawo spółek handlowych. Orzecznictwo 2009-2010, red. R. Kwaśnicki, P. Letolc, Legalis/ el. 2011.

Opalski A., Prawo zgrupowań spótek, Warszawa 2012.

Pełczyński M., Przedsiębiorstwo (art. 55[1] KC) wielopodmiotowe - istota i reżim prawny (cz. I), „Monitor Prawniczy” 2017, nr 3.

Prawo spótek handlowych. Orzecznictwo 2009-2010, red. K. Kwaśnicki, P. Letolc, Legalis/el. 2011.

Rudnicki K., Uzależnienie działania zarządu spótki kapitałowej od decyzji innych organów spótki, „Monitor Prawniczy” 2000, nr 7.

System Prawa Handlowego, t. 2. Prawo spótek handlowych, red. S. Włodyka, Warszawa 2012.

System Prawa Prywatnego, t. 5. Prawo zobowiązań - część ogólna, red. E. Łętowska, Warszawa 2012.

System Prawa Prywatnego, t. 17A. Prawo spółek kapitałowych, red. S. Sołtysiński, Warszawa 2015. System Prawa Prywatnego, t. 17B. Prawo spótek kapitałowych, red. S. Sołtysiński, Warszawa 2016.

\section{Akty prawne}

Rozporządzenie Prezydenta Rzeczypospolitej z dnia 27 czerwca 1934 roku Kodeks handlowy, Dz.U. z 1934 r. Nr 57, poz. 502).

Ustawa z dnia 23 kwietnia 1964 roku Kodeks cywilny, Dz.U. z 1964 r. Nr 16, poz. 93.

Ustawa z dnia 17 listopada 1964 roku Kodeks postępowania cywilnego, Dz.U. z 1964 r. Nr 43, poz. 296.

Ustawa z dnia 15 września 2000 roku Kodeks spółek handlowych, Dz.U. z 2000 r. Nr 94, poz. 1037.

\section{Orzecznictwo}

Postanowienie SN z dnia 22 grudnia 1997 roku, III CZ 104/97, Legalis Nr 44354.

Uchwała Sądu Najwyższego 7 sędziów — zasada prawna z dnia 7 stycznia 1967 roku, III CZP 32/66, OSNC 1968/12/199.

Wyrok SN z dnia 23 października 2003 roku, sygn. V CK 411/02, „Monitor Prawniczy” 2004/9/417. Wyrok SN z dnia 10 listopada 2004 roku, II CK 186/04, LEX nr 197641.

Wyrok SN z dnia 6 lutego 2009 roku, sygn. IV CSK 271/08, LEX nr 529733. 


\section{The consent of the general meeting of the shareholders of a joint stock company for the sale of assets of this company}

\section{Summary}

There is a lack of sufficient regulation related to the holding law. It is not clear what falls within the scope of the meaning "enterprise" in light of the Article 55 of Civil Code. It is not possible to predict that every enterprise managing other companies is not an enterprise within the meaning of Civil Code. In a particular case, it can be demonstrated that an enterprise is only managing other companies. But in an absence of sufficient connections between companies this regulation should be interpreted in accordance with its purpose - shareholder protection. All leads to the conclusion: in the current legal order, the competences provided in Article 393 shall be interpreted restrictively, because these are exceptional regulations. The restrictions relate to the sale of significant company assets (real estates and enterprises) which may affect the company's condition. This conclusions could apply to the limited liability company, taking into account the differences in the construction of a joint stock company and a limited liability company. 